\title{
Teaching NeuroImages: Isolated pontine involvement in subacute sclerosing panencephalitis
}

Niraj Kumar, MD, DM, Abhay Ranjan, MD, DM, Ashok Kumar, MD, DM, and Biswanath Kumar, MD, DM Neurology ${ }^{\circledR}$ 2018;91:e293-e294. doi:10.1212/WNL.0000000000005823

\section{Correspondence}

Dr. N. Kumar

drnirajkumarsingh@

gmail.com

Figure 1 Generalized, periodic sharp and slow-wave complexes on EEG

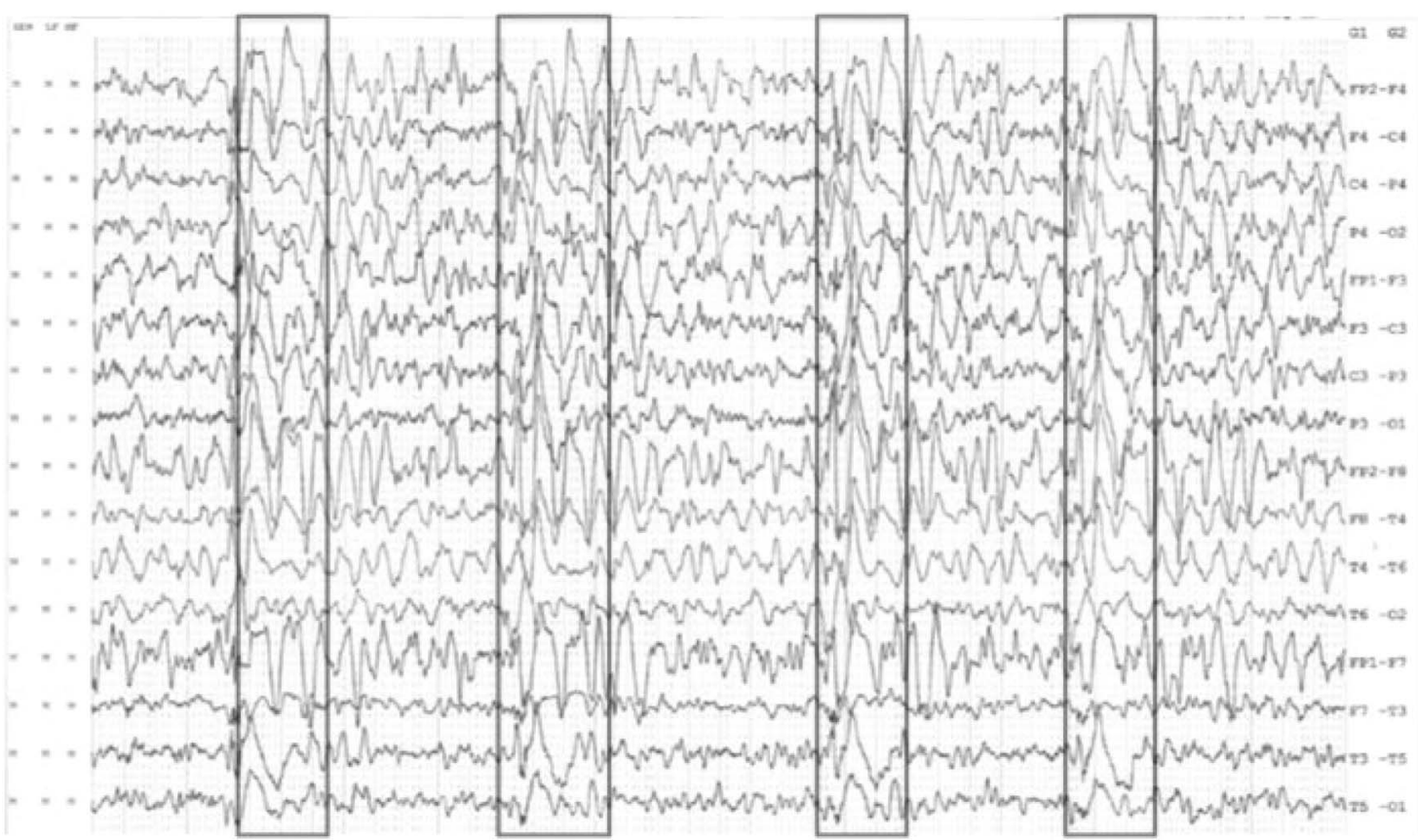

EEG shows generalized, periodic, stereotyped, high-amplitude sharp and slow-wave discharges lasting for 1-2 seconds and occurring every 5-7 seconds.

A 16-year-old boy, with history of measles at age 4, developed generalized myoclonic jerks and progressive decline in cognition and sensorium over 6 months. Generalized, periodic, highamplitude discharges on EEG (figure 1) and immunoglobulin G anti-measles antibody titer of $212.33 \mathrm{U} / \mathrm{mL}$ (normal $8 \mathrm{U} / \mathrm{mL}$ ) in CSF suggested subacute sclerosing panencephalitis (SSPE). MRI brain showed isolated T2 hyperintensities in ventral pons and middle cerebellar peduncles (figure 2). Despite symptomatic therapy, he died of cardiac arrest at 3 weeks. MRI brain commonly reveals cerebral cortices and periventricular white matter involvement in SSPE. ${ }^{1}$ Brainstem lesions are rare, ${ }^{1}$ with isolated involvement reported in a single case. ${ }^{2}$ Early brainstem involvement suggests aggressive course. ${ }^{1}$
MORE ONLINE

$\rightarrow$ Teaching slides

links.lww.com/WNL/

A581 
Figure 2 Isolated pontine involvement on MRI of the brain

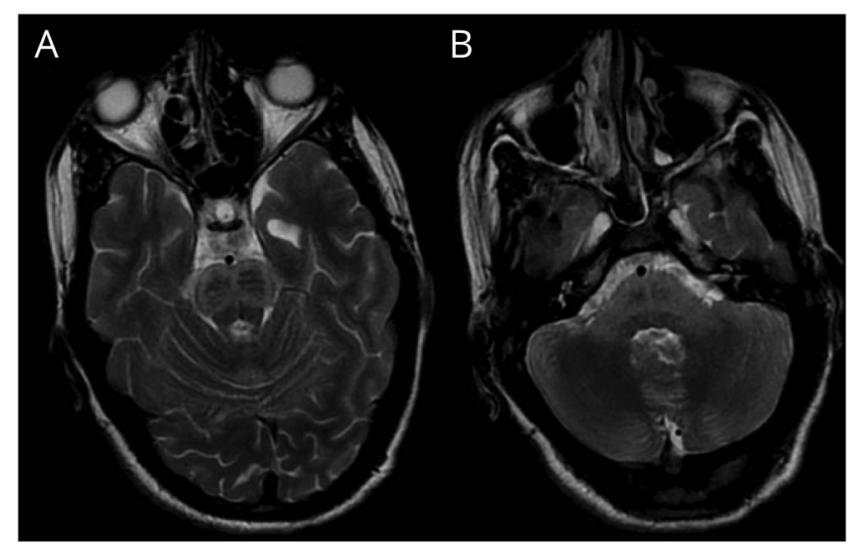

MRI of the brain shows hyperintensities in ventral pons $(A, B)$ and bilateral middle cerebellar peduncles (B) on T2-weighted images.

\section{Author contributions}

Dr. Niraj Kumar: conception, design, and writing the first manuscript. Dr. Abhay Ranjan: review and critique. Dr. Ashok Kumar: review and critique. Dr. Biswanath Kumar: review and critique.

\section{Study funding}

No targeted funding reported.

\section{Disclosure}

The authors report no disclosures relevant to the manuscript. Go to Neurology.org/N for full disclosures.

\section{References}

1. Upadhyayula P, Yang J, Yue J, Ciacci J. Subacute sclerosing panencephalitis of the brainstem as a clinical entity. Med Sci 2017;5:26.

2. Yilmaz C, Çaksen H, Yilmaz N, Güven AS, Bayram I. Two cases of subacute sclerosing panencephalitis associated with brainstem involvement. J Trop Pediatr 2007;53: 280-283. 


\section{Neurology}

\section{Teaching NeuroImages: Isolated pontine involvement in subacute sclerosing panencephalitis}

Niraj Kumar, Abhay Ranjan, Ashok Kumar, et al.

Neurology 2018;91;e293-e294

DOI 10.1212/WNL.0000000000005823

\section{This information is current as of July 16, 2018}

Updated Information \& Services

References

Permissions \& Licensing

Reprints including high resolution figures, can be found at: http://n.neurology.org/content/91/3/e293.full

This article cites 2 articles, 0 of which you can access for free at: http://n.neurology.org/content/91/3/e293.full\#ref-list-1

Information about reproducing this article in parts (figures,tables) or in its entirety can be found online at:

http://www.neurology.org/about/about_the_journal\#permissions

Information about ordering reprints can be found online: http://n.neurology.org/subscribers/advertise

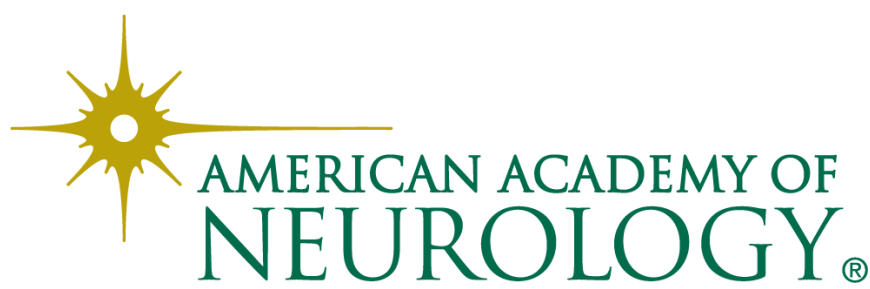

